Provided for non-commercial research and education use. Not for reproduction, distribution or commercial use.

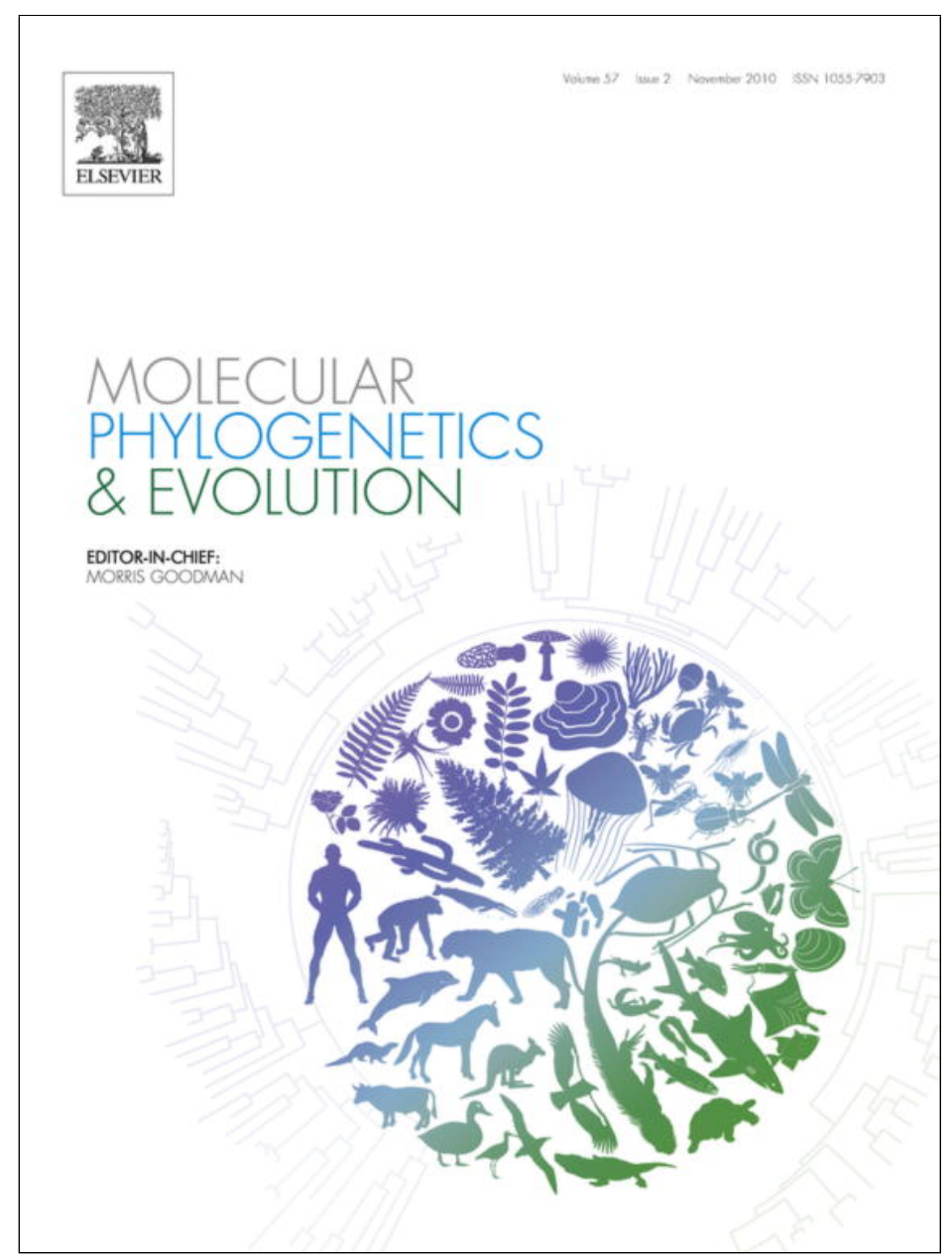

This article appeared in a journal published by Elsevier. The attached copy is furnished to the author for internal non-commercial research and education use, including for instruction at the authors institution and sharing with colleagues.

Other uses, including reproduction and distribution, or selling or licensing copies, or posting to personal, institutional or third party websites are prohibited.

In most cases authors are permitted to post their version of the article (e.g. in Word or Tex form) to their personal website or institutional repository. Authors requiring further information regarding Elsevier's archiving and manuscript policies are encouraged to visit:

http://www.elsevier.com/copyright 


\section{On tree frog cryptozoology and systematics - response to Y. Werner}

According to Werner (2010), we (Stöck et al. 2008) arbitrarily unsettled the systematics of two species of tree frogs (resp. Hyla savignyi and $H$. heinzsteinitzi), endangering their survival. Though fully aware and respectful of Werner's major herpetological contributions (e.g. Werner 1998 and Ref. therein), we have to reject these accusations and we provide here below a point-by-point rebuttal.

\section{Hyla savignyi}

1a: Based on both mitochondrial and nuclear markers, we found the traditionally recognized $H$. savignyi to represent two very well supported monophyletic lineages (Stöck et al. 2008), and proposed to assign the southern lineage to a "new taxon 3". According to Werner (2010), our genetic data do not allow taking this step; the genetic differences found might simply represent a gradual cline. He possibly missed the recent paper by Gvoždík et al. (2010), who fully confirm our interpretation based on additional and different sequence markers, and described our "taxon 3 " as a new species (Hyla felixarabica). As these authors show, $H$. felixarabica differs from other Hyla species not only on genetics, but also regarding morphology and advertisement call, and occurs in sympatry and syntopy with $H$. savignyi in Israel.

1b: Werner (2010) claims that we are violating the rules of nomenclature by assigning the original taxonomic name $(H$. savignyi) to the northern lineage. He and coauthors (Grach et al. 2007) reviewed the nomenclature of $H$. savignyi Audouin, 1827, mysteriously described from "Egypt" (where no tree frogs occur) and considered it to be widespread from "Turkey, Transcaucasia and northwestern Iran over Syria and Lebanon to central Jordan and Israel and the southwestern Arabian Peninsula". No type material of Audouin's description is available, and representatives of both species occur in Syria, Jordan and Israel (Gvoždík et al. 2010), the speculative type region of $H$. savignyi Audouin. Thus, it was a delicate decision to which of the two Hyla taxa the name savignyi should be assigned. Given that there are many more papers that have previously used the name Hyla savignyi for tree frogs from Turkey, Cyprus, and Syria (Iran and Iraq) (e.g. references in Schneider 2009), we proposed to restrict the name to the northern taxon. Under the Code on Zoological Nomenclature (ICZN 1999), there is also the principle of stability (Article 23.2), which recommends avoiding confusion by nomenclatural changes. Our proposal to leave the name with the northern taxon circumvents too many changes. It seemed also recommended at publication of our article (Stöck et al. 2008) for the improbable case that the name $H$. heinzsteinitzi would turn out to become applicable, as a senior synonym, to the southern taxon (now H. felixarabica). Note also that our decision was fully corroborated by the later study of Gvoždík et al. (2010), according to which the northern lineage "corresponds to H. savignyi sensu stricto (hereafter as only $H$. savignyi) because it includes specimens from the putative type locality".

1c: We do not understand the claim that assigning the southern lineage to a new taxon (H. felixarabica) should hamper its conservation. Quite to the contrary, we think this new status should even help conservation efforts, and this seems also to be the logics applied by Werner (2010) when it comes to H. heinzsteinitzi.

\section{Hyla heinzsteinitzi}

2a: Werner and coauthors (Grach et al. 2007) described the new species $H$. heinzsteinitzi, from three ponds around Jerusalem, based on differences in morphology and bioacoustics from the local $H$. savignyi. Caution is required when describing new species from morphologically similar but species-rich groups as Hylidae, especially in relatively species-poor and well-studied regions, in order to avoid double-descriptions. Nowadays, while this is not always possible, it seems highly recommended to provide standard DNA markers along with classical morphological descriptions and/or to deposit DNA or tissue samples in publically accessible, scientific collections for later genetic characterizations. The omission of this caused most if not all of the "cryptozoology" (e.g. Colman and Clark 1999) we are dealing with now.

To obtain a tissue sample of $H$. heinzsteinitzi, one of us (S. Litvinchuk) had contacted Y. Werner (ca. October 2007) and, independently, M. Stöck had emailed C. Grach in March 2008, first author of the above study. Both kindly referred to B. Shacham, collection manager of the herpetological collection at the Jerusalem University, who finally sent a piece of tadpole to one of us (S. Litvinchuk). As a result of our DNA analyses, "we found two mtDNA fragments (COI, Cyt b; Appendix 1) from a single, topotypic sample [of Hyla heinzsteinitzi] (Mamila reservoir, Jerusalem) to be almost identical to homologous sequences of $H$. japonica (AB303949)", a species from East Asia. We therefore recommended "a careful comparison of morphometric data and sequencing of additional samples" (Stöck et al. 2008).

After being contacted by Y. Werner on January 10, 2010, with accusations similar to the ones published here, we reiterated our offer of sequencing standard DNA markers from additional samples, using non-invasive buccal swabs (Broquet et al. 2007), but without success. Apparently, Werner also refused to share tissue samples with a colleague who personally visited the Jerusalem collection (Gvoždík, pers. comm.). Given this, and his plaid for a "complete and genome-wide investigation", it is astonishing that Werner has so far not managed to provide additional sequences of this elusive species, to potentially proof us wrong.

2b: If additional genetic analyses do confirm our suggestion, then there is no doubt that the conservation status of these three Jerusalem populations will be affected. However, we have to 
strongly reject any form of responsibility in potential threats. First, these populations had already almost entirely vanished before our paper appeared. As written by B. Shacham on March 22, 2008 (copied to Y. Werner and C. Grach): "The situation regarding Hyla heinzsteinitzi is at the moment foggy, at best. At the type locality (Mamila pond, Jerusalem) as well as many other potential loci there are various disturbances, among them pollution, introduced predators (Gambusia fishes) and in recent years drying due to drought conditions." Second, and more importantly, taxonomy should be kept independently of considerations other than scientific ones. In this respect, though we completely share Werner's motivations for amphibian conservation, we do not think they should conquer phylogenetics and systematics.

Summary: We reject the opinion of Werner (2010) that our phylogenetic studies of circum- Mediterranean tree frogs arbitrarily unsettled the systematics and endangered species. Our recognition of two monophyletic lineages within the formerly described H. savignyi has since been fully corroborated by Gvoždík et al. (2010) who described the southern lineage as a new species (H. felixarabica), clearly distinct form other Hyla species based on genetics, morphology and bioacoustics. In the absence of both type material and a precisely defined type locality for savignyi (Grach, Plesser and Werner, 2007), we agree with Gvoždík et al. (2010) to apply the name Hyla savignyi to the northern lineage, as populations from this region have been widely examined under this name. Regarding H. heinzsteinitzi, given data in hand, we can only repeat our suggestion of a recent $\mathrm{H}$. japonica introduction into Jerusalem, and recommend careful comparison of morphometric data and sequencing of additional samples. Regarding interactions between conservation and systematics, we make the point that decisions on taxonomic entities cannot depend on their conservation status, though we share motivations for amphibian conservation.

\section{Acknowledgment}

We thank the editor-in-chief, Morris Goodman, for the kind opportunity to write this response.

\section{References}

Colman, L., Clark, C., 1999. Cryptozoology from A to Z. The Encyclopedia of Loch Monsters, Sasquatch, Chupacabras and other Authentic Mysteries of Nature. Simon and Schuster, NY.

Broquet, T., Berset-Brändli, L., Emaresi, G., Fumagalli, L., 2007. Buccal swabs allow efficient and reliable microsatellite genotyping in amphibians. Conserv. Genet. 8, 509-511.

Grach, C., Plesser, Y., Werner, Y.L., 2007. A new, sibling, tree frog from Jerusalem (Amphibia: Anura: Hylidae). J. Nat. Hist. 41 (9-12), 709-728.
Gvoždík, V., Moravec, J., Klütsch, C., Kotlík, P., 2010. Phylogeography of the Middle Eastern tree frogs (Hyla, Hylidae, Amphibia) as inferred from nuclear and mitochondrial DNA variation, with a description of a new species. Mol. Phylogenet. Evol. 55, 1146-1166.

ICZN [International Commission on Zoological Nomenclature], 1999. International Code of Zoological nomenclature, forth ed.. La Garangola, Padua.

Schneider, H., 2009. Hyla savignyi Audouin, 1827 - Mittelöstlicher Laubfrosch. In: Grossenbacher, K. (Ed.), Handbuch der Reptilien und Amphibien Europas. Band 5/II: Froschlurche (Anura) II (Hylidae, Bufonidae). Wiebelsheim, Aula-Verlag. pp. 141-172.

Stöck, M., Dubey, S., Klütsch, C., Litvinchuk, S.N., Scheidt, U., Perrin, N., 2008. Mitochondrial and nuclear phylogeny of circum-Mediterranean tree frogs from the Hyla arborea group. Mol. Phylogenet. Evol. 49, 1019-1024.

Werner, Y., 1998. The desert herpetofauna in and near Israel: a personal review of advances (1986-1997), with new data (Amphibia, Reptilia). Faunist. Abhandl. Staatl. Mus. Tierkd. Dresden 21(Suppl.), 149-161.

Matthias Stöck

Department of Ecology and Evolution, University of Lausanne, Biophore, CH-1015 Lausanne, Switzerland Fax: +41216924165. E-mail address: matthias.stoeck@unil.ch

Sylvain Dubey

Department of Ecology and Evolution, University of Lausanne, Biophore, CH-1015 Lausanne, Switzerland Heydon-Laurence-Building A08, University of Sydney, NSW 2006, Australia E-mail address: s.dubey@usyd.edu.au

Cornelya Klütsch Zoologisches Forschungsmuseum Alexander Koenig, Adenauerallee 160, D-53113 Bonn,

Germany

E-mail address: cornelya.kluetsch@biotech.kth.se

Spartak N. Litvinchuk Institute of Cytology, Russian Academy of Sciences, Tikhoretsky pr. 4, 194064 St. Petersburg, Russia

E-mail address: slitvinchuk@yahoo.com

Ulrich Scheidt Naturkundemuseum Erfurt, Grosse Arche 14, D-99084 Erfurt, Germany

E-mail address: ulrich.scheidt@erfurt.de

Nicolas Perrin Department of Ecology and Evolution, University of Lausanne, Biophore, CH-1015 Lausanne, Switzerland E-mail address: nicolas.perrin@unil.ch 